\title{
Redox-stat bioreactors for elucidating mobilisation mechanisms of trace elements: an example of As-contaminated mining soils
}

\author{
Liwia Rajpert $^{1,2}$ - Andreas Schäffer ${ }^{2} \cdot$ Markus Lenz $^{1,3}$ (D)
}

Received: 27 April 2018 /Revised: 5 June 2018 / Accepted: 6 June 2018 / Published online: 21 June 2018

(C) The Author(s) 2018

\begin{abstract}
The environmental fate of major (e.g. C, N, S, Fe and Mn) and trace (e.g. As, Cr, Sb, Se and U) elements is governed by microbially catalysed reduction-oxidation (redox) reactions. Mesocosms are routinely used to elucidate trace metal fate on the basis of correlations between biogeochemical proxies such as dissolved element concentrations, trace element speciation and dissolved organic matter. However, several redox processes may proceed simultaneously in natural soils and sediments (particularly, reductive $\mathrm{Mn}$ and Fe dissolution and metal/metalloid reduction), having a contrasting effect on element mobility. Here, a novel redox-stat $\left(R_{\text {cont }}\right)$ bioreactor allowed precise control of the redox potential $(159 \pm 11 \mathrm{mV}, \sim$ 2 months), suppressing redox reactions thermodynamically favoured at lower redox potential (i.e. reductive mobilisation of Fe and As). For a historically contaminated mining soil, As release could be attributed to desorption of arsenite [As(III)] and $\mathrm{Mn}$ reductive dissolution. By contrast, the control bioreactor $\left(R_{\text {nat }}\right.$, with naturally developing redox potential) showed almost double As release (337 vs. $\left.181 \mu \mathrm{g} \mathrm{g}^{-1}\right)$ due to reductive dissolution of $\mathrm{Fe}\left(1363 \mu \mathrm{g} \mathrm{g}^{-1} \mathrm{Fe}^{2+}\right.$ released; no $\mathrm{Fe}^{2+}$ detected in $\left.R_{\text {cont }}\right)$ and microbial arsenate $[\mathrm{As}(\mathrm{V})]$ reduction $\left(189 \mu \mathrm{g} \mathrm{g}^{-1}\right.$ released vs. $46 \mu \mathrm{g} \mathrm{g}^{-1} \mathrm{As}(\mathrm{III})$ in $\left.R_{\text {cont }}\right)$. A redoxstat bioreactor thus represents a versatile tool to study processes underlying mobilisation and sequestration of other trace elements as well.
\end{abstract}

Keywords Arsenic remediation $\cdot$ Redox-stat bioreactor $\cdot$ Trace element fate

\section{Introduction}

In the former mining area of the Złoty Stok (Lower Silesia, southwest Poland), long-lasting mining activities together with lack of reclamation resulted in As contamination $\left(>2000 \mu \mathrm{g} \mathrm{g}^{-1}\right.$ soil) of the nearby valley (i.e.

Electronic supplementary material The online version of this article (https://doi.org/10.1007/s00253-018-9165-4) contains supplementary material, which is available to authorized users.

Markus Lenz

markus.lenz@wur.nl

1 Institute for Ecopreneurship, School of Life Sciences, University of Applied Sciences and Arts Northwestern Switzerland, Gründenstrasse 40, 4132 Muttenz, Switzerland

2 Institute for Environmental Research (Biology V), RWTH Aachen University, 52074 Aachen, Germany

3 Sub-Department of Environmental Technology, Wageningen University, 6700 EV Wageningen, The Netherlands
Trująca Valley) (Krysiak and Karczewska 2007). Elevated concentrations of $\mathrm{As}, \mathrm{Hg}, \mathrm{Cr}$ and/or $\mathrm{Mn}$ were found in surface and ground waters (Marszałek and Wasik 2000). Nevertheless, the lower part of the Trujaca Valley is still used agriculturally, which may pose a risk of As entry into the human food chain (Krysiak and Karczewska 2007; Karczewska et al. 2013). Potential mobility and bioavailability of As are dependent on As speciation and the physicochemical properties of the host matrix (i.e. identity and quantity of sorbing phases) (Borch et al. 2010). Under oxidising conditions, which prevail in top soils during dry conditions, As is thermodynamically favoured to exist in the form of negatively charged arsenate $[\mathrm{As}(\mathrm{V})]$, which has a high affinity to $\mathrm{Fe} /$ Mn-(oxyhydr)oxides (Ehlert et al. 2014; Couture et al. 2015). Upon water logging (e.g. as a result of flooding or rainfall after soil compaction), reducing conditions can be induced by decreased diffusion and fast microbial consumption of residual atmospheric oxygen. Such reducing conditions favour microbially catalysed reduction of 
arsenate to arsenite $[\mathrm{As}(\mathrm{III})]$ (by dissimilatory arsenate reducing bacteria), which can result in As mobilisation owing to the low sorption capacity on major soil phases (Giménez et al. 2007). Further, Fe/Mn-(oxyhydr)oxides are prone to microbially catalysed reductive dissolution therewith mobilising sequestered As (as well as other trace elements and radionuclides) (Ehlert et al. 2014; Couture et al. 2015; Zhang et al. 2014).

Mesocosms are typical laboratory systems used to study mechanisms of As and other trace element mobilisation for risk assessment. Typically, contaminated soil/sediment slurry samples are incubated over time, and conclusions on the underlying mobilisation and sequestration processes are made on the basis of correlations between biogeochemical proxies (e.g. dissolved $\mathrm{Fe}$ and $\mathrm{Mn}$, dissolved organic matter, $\mathrm{pH}$, redox potential) and the elements mobilised (as either the total element mobilised or elemental species) (Masscheleyn et al. 1991; Kneebone and Hering 2000; Hockmann et al. 2014). In biogeochemistry, the redox potential $\left(E_{\mathrm{h}}\right)$ is measured as it reflects the tendency of a system to undergo redox reactions and provides support for conclusions by thermodynamic equilibrium modelling of favoured species. If not supported by further analysis, such as spectroscopy and molecular biology analysis, the conclusions obtained may be biased because several (redox) reactions may overlay (particularly in structurally heterogeneous systems) or be kinetically hindered, although thermodynamically favoured. However, $E_{\mathrm{h}}$ not only serves as a proxy of prevalent reactions that occur in a system indicating the availability of electrons in the system, but can also be used to actively suppress unwanted reactions by making the reaction thermodynamically unfavoured. More precisely, soil/sediment slurries that are not in contact with ambient oxygen tend to a decreasing $E_{\mathrm{h}}$ because of the consumption of organic electron donors (either natural or supplied). Then by feeding finite amounts of a preferred external electron acceptor (oxygen), the $E_{\mathrm{h}}$ can be ultimately maintained at intermediary values between fully reducing and fully oxidising conditions. This renders all redox reactions occurring at a lower potential thermodynamically unfavourable.

In this study, such a redox-stat bioreactor was designed to quantify the contributions of Fe,Mn-(oxyhydr)oxide reductive dissolution and arsenate reduction on overall As mobilisation in historically contaminated mining soils. In the redox stat $\left(R_{\text {cont }}\right), \mathrm{E}_{\mathrm{h}}$ was controlled at a true steady state where inbetween fully oxidising and fully reducing conditions ( $+150 \mathrm{mV}$ ) are maintained, allowing only for Mn reduction while supressing $\mathrm{Fe}$ and arsenate reduction. Elemental mobilisation as well as speciation in the developed reactor was compared with that of a control reactor with naturally developing redox potential $\left(R_{\text {nat }}\right)$ by inductively coupled plasma mass spectrometry (ICP-MS), X-ray fluorescence (XRF) and liquid chromatography-ICP-MS (LC-ICP-MS).

\section{Materials and methods}

\section{Source of soil, sampling and calculation of elemental mobilisation}

Soil samples were collected from a surface layer $(0-20 \mathrm{~cm})$ on the bank of the Trujaca River ("Poisonous Stream", drain of the former goldmine) and sample preparation was performed as described previously (Rajpert et al. 2016). Total element concentrations (using XRF), element mobilisation rates $\left(\mu \mathrm{g} \mathrm{L}^{-1} \mathrm{~h}^{-1}\right)$ and cumulative element mobilised ( $\mu \mathrm{g} \mathrm{g}^{-1}$ of soil) were determined as described previously (Rajpert et al. 2016).

\section{Bioreactor operation}

Two continuous stirred-tank reactors (CSTR, Multifors, Infors HT, Bottmingen, Switzerland) were operated at a slurry concentration of $10 \%$ soil $(w / v)$ under mesophilic $\left(21 \pm 5^{\circ} \mathrm{C}\right)$ and slightly alkaline conditions $(\mathrm{pH}=8.0 \pm 0.6$, using automated acid or base dosing) for $1368 \mathrm{~h}$ (57 days). The hydraulic retention time was set to $48 \mathrm{~h}$. The reactors were continuously fed with filtered $(0.22 \mu \mathrm{m})$, degassed minimal medium (Rajpert et al. 2016). Lactate $\left(0.11 \mathrm{~g} \mathrm{~L}^{-1}\right)$ was added at an organic loading rate of $48 \mathrm{mg} \mathrm{COD} \mathrm{L}{ }^{-1}$ day $^{-1}$ (Chemical Oxygen Demand), supplying an excess of electrons based on the total As concentration. A constant flow of $\mathrm{N}_{2}$ was maintained through the reactor headspace during operation. In both reactors, the redox potential was monitored with a silver-free gel electrode (QIS, Oosterhout, The Netherlands). The redox potential in the first reactor developed naturally over time (referred to as " $R_{\text {nat }}$ "), while in the second reactor, the redox potential was controlled (referred to as " $R_{\text {cont }}$ "). The set-point of $+160 \mathrm{mV}$ was maintained by short doses of synthetic air $\mathrm{N}_{2}: \mathrm{O}_{2}(80: 20)$ at $3 \mathrm{~L} \mathrm{~min}^{-1}$. Air flow was switched on/off by a controller (Standard Digital Redox-Processor No: 2/VIII; Trop-Electronic GmbH, Luedenscheid, Germany) via a $240-\mathrm{V}$ solenoid valve.

\section{Liquid phase analysis}

Samples $(\sim 20 \mathrm{~mL})$ were sequentially centrifuged (4500 rcf, $10 \mathrm{~min}, 21^{\circ} \mathrm{C}$ ) and filtered (sequential; 0.45 and $0.2 \mu \mathrm{m}$ pore size, Whatman, Hertogenbosch, The Netherlands). The concentration of total dissolved As, $\mathrm{Mn}$ and Fe were quantified on an Agilent 7500cx ICP-MS (Agilent Technologies AG, Basel, Switzerland) with standard settings (Zimmermann et al. 2013) at masses ${ }^{56} \mathrm{Fe},{ }^{55} \mathrm{Mn}$ and ${ }^{75} \mathrm{As}$. Mn and As were measured in the collision mode using helium, whereas Fe was measured in the reaction mode using $\mathrm{H}_{2}$. Speciation analysis was performed by LC-ICP-MS, as previously described, after preservation of the samples in EDTA/AcOH (Gallagher et al. 2004). Preserved samples were stored at $4{ }^{\circ} \mathrm{C}$ and measured within 
$72 \mathrm{~h}$ after sampling. The concentration of dissolved iron $\left(\mathrm{Fe}^{2+}\right)$ was measured spectrophotometrically with 1.10phenantroline after preservation in $0.5 \mathrm{M} \mathrm{HCl}$ (Fadrus and Malý 1975).

\section{Results}

\section{Element mobilisation}

The mobilisation of As in $R_{\text {nat }}$ showed initially high rates (maximal mobilisation rate $99.1 \mu \mathrm{g} \mathrm{L}^{-1} \mathrm{~h}^{-1}$ at $144 \mathrm{~h}$ ) followed by a gradual decrease and a nearly constant, low As release until the end of reactor operation (minimal mobilisation rate $1.4 \mu \mathrm{g} \mathrm{L}^{-1} \mathrm{~h}^{-1}$ at $1272 \mathrm{~h}$ ) (Fig. 1a). By contrast, both Fe and Mn were released steadily throughout the reactor operation (indicated by the straight lines in cumulative element released, Fig. 1b, c). Fe reducing conditions developed during the first $\sim 192$ h (Fig. 2), resulting in steadily increasing Fe mobilisation; whereas later, Fe was mobilised rather constantly (average $119.0 \pm 35.8 \mu \mathrm{g} \mathrm{L}^{-1} \mathrm{~h}^{-1}$, maximal mobilisation rate $204.5 \mu \mathrm{g} \mathrm{L}^{-1} \mathrm{~h}^{-1}$ at $432 \mathrm{~h}$ ) until the introduction of oxidising conditions $(+0.2 \pm 0.3 \mathrm{~V})$ at $1272 \mathrm{~h}$ (Fig. 1b). Mn reducing conditions developed more rapidly (from the start of the reactor operation), resulting initially in high mobilisation rates (maximal mobilisation rate $85.3 \mu \mathrm{g} \mathrm{L}^{-1} \mathrm{~h}^{-1}$ at $48 \mathrm{~h}$ ), followed by a gradual decrease. An exceptionally high $\mathrm{Mn}$ mobilisation rate $\left(113 \mu \mathrm{g} \mathrm{L}^{-1} \mathrm{~h}^{-1}\right)$ was observed on a single sampling only and was potentially an outlier, since it occurred in both reactors. For the remaining reactor operation, $\mathrm{Mn}$ mobilisation was rather constant at around $40 \mu \mathrm{g} \mathrm{L}^{-1} \mathrm{~h}^{-1}$ (Fig. 1c). Overall, $337 \mu \mathrm{g} \mathrm{g}^{-1}$ of As ( 17\% of total As), $1448 \mu \mathrm{g} \mathrm{g}^{-1}$ of $\mathrm{Fe}(\sim 3 \%$ of total $\mathrm{Fe})$ and $632 \mu \mathrm{g} \mathrm{g}^{-1}$ of $\mathrm{Mn}$ ( $\sim 54 \%$ of total $\mathrm{Mn}$ ) were mobilised during the $R_{\text {nat }}$ reactor operation until re-oxidation (Fig. 1a-c and Table 1).

In $R_{\text {cont }}$, initial As mobilisation was lower and decreased faster in comparison to $R_{\text {nat }}$ (Fig. 1a). Fast mobilisation (comparable to $R_{\text {nat }}$ ) was observed only until $\sim 96 \mathrm{~h}$, illustrated by the virtually identical lines of cumulative element mobilised (Fig. 1a). Subsequently, As mobilisation rate decreased until $\sim 500 \mathrm{~h}$, after which hardly any As was mobilised (minimal mobilisation rate $2.3 \mu \mathrm{g} \mathrm{L}^{-1} \mathrm{~h}^{-1}$ at $1272 \mathrm{~h}$; Fig. 1a). As mobilisation rates in $R_{\text {cont }}$ remained lower than in $R_{\text {nat }}$ throughout the reactor operation. In contrast to $R_{\text {nat }}$, the $\mathrm{Fe}$ mobilisation rate in $R_{\text {cont }}$ was lower and relatively stable during the reactor operation with an average mobilisation of 46.6 $\pm 21.5 \mu \mathrm{g} \mathrm{L}^{-1} \mathrm{~h}^{-1}$ (maximal mobilisation rate 107.2 $\mu \mathrm{g} \mathrm{L}^{-1} \mathrm{~h}^{-1}$ at $192 \mathrm{~h}$, minimal mobilisation rate $7.2 \mu \mathrm{g} \mathrm{L}^{-1} \mathrm{~h}^{-1}$ at 576-624 h; Fig. 1b). Dissolution of manganese in the $R_{\text {cont }}$ reactor was quite similar to the $R_{\text {nat }}$ (Fig. 1c). Overall, $181 \mu \mathrm{g} \mathrm{g}^{-1}$ of As ( 9\% of total As), $578 \mu \mathrm{g} \mathrm{g}^{-1}$ of Fe $\left(\sim 1 \%\right.$ of total Fe, exclusively as colloidal Fe) and $625 \mu \mathrm{g} \mathrm{g}^{-1}$ of $\mathrm{Mn}(\sim 54 \%$ of total $\mathrm{Mn})$ were mobilised during the $R_{\text {cont }}$ reactor operation (Fig. 1a-c and Table 1).

Upon re-oxidation, both reactors showed similar effects on $\mathrm{Fe}$ and $\mathrm{Mn}$ mobilisation rates, decreasing to virtually zero (Fig. 1b, c), whereas there was already hardly any As mobilised before oxidation (Fig. 1a).

\section{Redox potential and speciation analysis}

$R_{\text {cont }}$ indeed allowed to precisely control $E_{\mathrm{h}}$ at $159 \pm 11 \mathrm{mV}$ over a period of $>50$ days, whereas in $R_{\text {nat }}$, the redox potential decreased due to microbial activity to $\mathrm{As}(\mathrm{V})$-reducing and $\mathrm{Fe}(\mathrm{III})$-reducing (both $\sim-120 \mathrm{mV}$ ) conditions from around $72 \mathrm{~h}$ (Fig. 2). At the conditions specified in Takeno (2005), reduced species $\left(\mathrm{H}_{3} \mathrm{AsO}_{3}\right.$; arsenite; $\mathrm{As}(\mathrm{III})$ and $\left.\mathrm{FeOH}^{+} ; \mathrm{Fe}^{2+}\right)$ were favoured thermodynamically in $R_{\text {nat }}$ already after $72 \mathrm{~h}$ of operation. Indeed, there was a sustained release of $\mathrm{As}(\mathrm{V})$ in $R_{\text {cont }}$ during the entire reactor operation (Fig. 3a), whereas hardly any $\mathrm{As}(\mathrm{V})$ released in $R_{\text {nat }}$ after $720 \mathrm{~h}$ until re-oxidation. The apparent difference in As speciation becomes even more visible when considering the share of As(III) in the total As released in the reactors (Fig. 3c).

The dissolution of both $\mathrm{As}(\mathrm{III})$ and $\mathrm{As}(\mathrm{V})$ in $R_{\mathrm{nat}}$ was characterised by high mobilisation rates initially $(0-240 \mathrm{~h})$ [As(III) maximal mobilisation rate $77.2 \mu \mathrm{g} \mathrm{L}^{-1} \mathrm{~h}^{-1}$ at $24 \mathrm{~h}$, $\mathrm{As}(\mathrm{V})$ maximal mobilisation rate $43.4 \mu \mathrm{g} \mathrm{L} \mathrm{L}^{-1} \mathrm{~h}^{-1}$ at $144 \mathrm{~h}$; Fig. 3b]. At $288 \mathrm{~h}$, concentrations of both species in the reactor effluent started to decrease steadily and this trend continued until the end of the reactor operation (Fig. 3b; As(III) minimal mobilisation rate $2.8 \mu \mathrm{g} \mathrm{L}^{-1} \mathrm{~h}^{-1}$ at $480 \mathrm{~h}, \mathrm{As}(\mathrm{V})$ minimal mobilisation rate $0.7 \mu \mathrm{g} \mathrm{L}^{-1} \mathrm{~h}^{-1}$ at $768 \mathrm{~h}$ ). Overall, $148.2 \mu \mathrm{g} \mathrm{g}^{-1}$ of $\mathrm{As}(\mathrm{V})(7 \%$ of total As) and $190.0 \mu \mathrm{g} / \mathrm{g}$ of
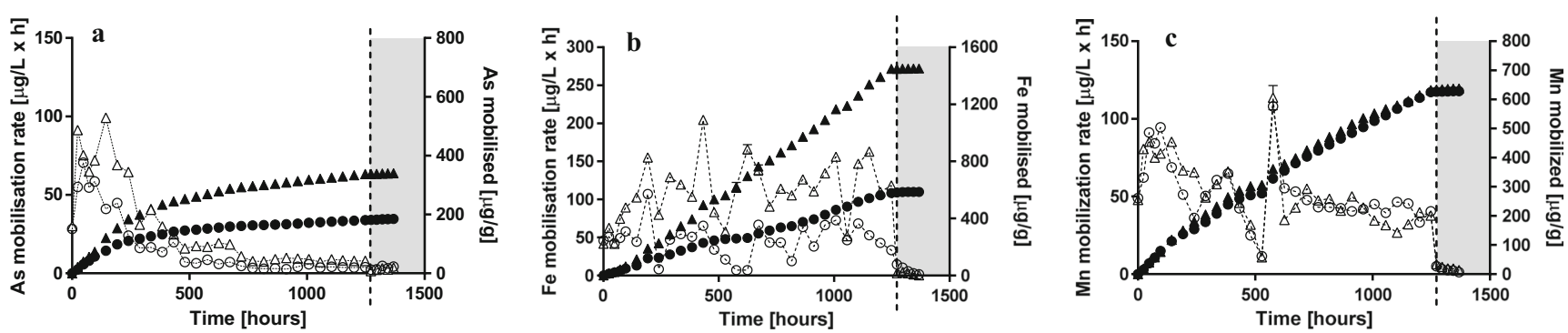

Fig. 1 Mobilisation of $\mathrm{As}(\mathbf{a}), \mathrm{Fe}(\mathbf{b})$ and $\mathrm{Mn}(\mathbf{c})$ in $R_{\text {cont }}$ (circles) and $R_{\text {nat }}$ (triangles) in terms of elemental mobilisation rate (open symbols, primary $Y$ axis) and total element mobilised (solid symbols, secondary $Y$-axis). The dashed line is representing the beginning of oxidising conditions 

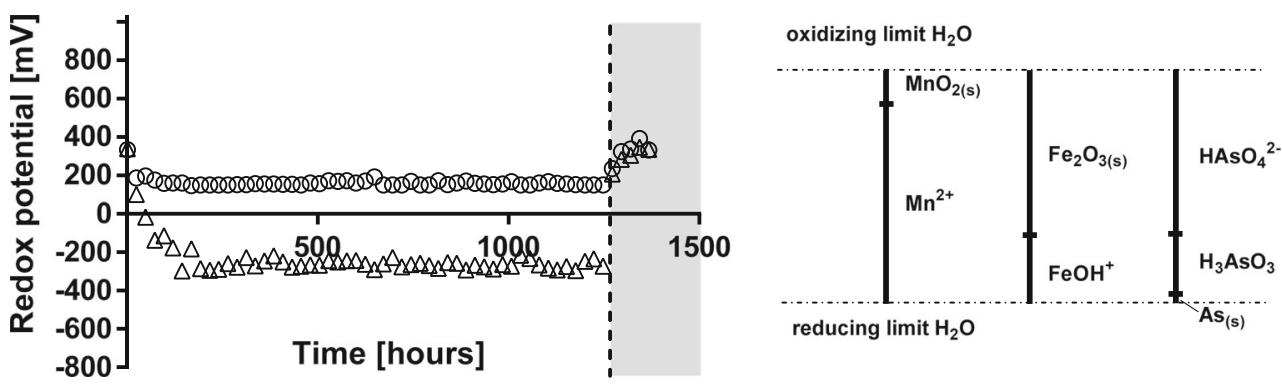

Fig. 2 Redox potential in $R_{\text {cont }}$ (circles) and $R_{\text {nat }}$ (triangles). The dashed line is showing the beginning of oxidising conditions. The solid lines (right side) are representing the thermodynamically favoured species at

pH 8.0 for Mn, Fe and As (FACT/FACTSAGE; $\sum$ As $/ \mathrm{Fe} / \mathrm{Mn}=10^{-10}$, $298.15 \mathrm{~K}, 10^{5} \mathrm{~Pa} ; \mathrm{Mn} / \mathrm{Fe}$ or As-O-H system, resp.) (Takeno 2005)

As(III) (9\% of total As) were mobilised in the $R_{\text {nat }}$ reactor. In $R_{\text {cont }}$ also there were high mobilisation rates of both As( $(\mathrm{V})$ and As(III) initially [As(V) maximal mobilisation rate $42.3 \mu \mathrm{g} \mathrm{L}^{-1} \mathrm{~h}^{-1}$ at $48 \mathrm{~h}$, As(III) maximal mobilisation rate $34.1 \mu \mathrm{g} \mathrm{L}^{-1} \mathrm{~h}^{-1}$ at $144 \mathrm{~h}$ ]. The mobilisation rate of the As(III) dropped drastically starting from $240 \mathrm{~h}$ onwards [As(III) was not detected within 336-672 h; Fig. 3a]. Overall, $140.5 \mathrm{\mu g} \mathrm{g}^{-1}$ of $\mathrm{As}(\mathrm{V})(7 \%$ of total As) and $47 \mu \mathrm{g} \mathrm{g}^{-1}$ of As(III) (2\% of total As) were mobilised in $R_{\text {cont }}$ (Fig. 3a).

Fe speciation was clearly different in $R_{\text {nat }}$ and $R_{\text {cont. }}$. Despite the total Fe mobilised (Fig. 1b) in $R_{\text {cont }}$, reduced $\mathrm{Fe}^{2+}$ was found exclusively in $R_{\text {nat }}$ (Fig. 4). Reduced $\mathrm{Fe}^{2+}$ was released starting at $72 \mathrm{~h}$ and throughout the reactor operation with an average rate of $93 \pm 54 \mu \mathrm{g} \mathrm{L}^{-1} \mathrm{~h}^{-1}$ (maximal mobilisation rate $195.4 \mu \mathrm{g} \mathrm{L}^{-1} \mathrm{~h}^{-1}$ at $432 \mathrm{~h}$, minimal mobilisation rate $48.9 \mu \mathrm{g} \mathrm{L}^{-1} \mathrm{~h}^{-1}$ at $1056 \mathrm{~h}$; Fig. 4). Overall, $1363.8 \mu \mathrm{g} \mathrm{g}^{-1}$ of reduced Fe $\left(2.5 \%\right.$ of the total Fe) were mobilised in the $R_{\text {nat }}$ reactor (Fig. 4).

\section{Experimental elemental recovery}

An XRF analysis showed considerable quantities of As $\left(2010 \mu \mathrm{g} \mathrm{g}^{-1}\right), \mathrm{Fe}\left(53,867 \mu \mathrm{g} \mathrm{g}^{-1}\right)$ and $\mathrm{Mn}\left(1164 \mu \mathrm{g} \mathrm{g}^{-1}\right)$ in the initial soil (SI, Table $\mathrm{S} 1)$. The soil residue after $R_{\text {nat }}$ reactor operation contained $1625 \mu \mathrm{g} \mathrm{g}^{-1}$ of As, $548 \mu \mathrm{g} \mathrm{g}^{-1}$ of Mn and $49,437 \mu \mathrm{g} \mathrm{g}^{-1}$ of $\mathrm{Fe}$, whereas $R_{\text {cont }}$ reactor showed higher residual $\mathrm{As}$ and $\mathrm{Fe}$ concentrations $\left(1727.0 \mu \mathrm{g} \mathrm{g}^{-1}\right.$ and $51,427 \mu \mathrm{g} \mathrm{g}^{-1}$, respectively), and comparable Mn content $\left(606 \mu \mathrm{g} \mathrm{g}^{-1}\right)$ (SI, Table S1). The differences in element concentrations between the initial and treated soil corresponded well to the cumulative element mobilised measured in the $R_{\text {nat }}$

and $R_{\text {cont }}$ reactor effluents (Table 1), resulting in closed element balances (experimental recoveries $95-106 \%$, Table S1). The experimental recovery for As species (i.e. As(III) and $\mathrm{As}(\mathrm{V})$ in comparison to total dissolved As) was generally around $100 \%$ (SI, Fig. S1).

\section{Discussion}

In this work, we applied for the first time a true redox-stat reactor to study mechanisms underlying trace element release of As from contaminated mining soils. The redox potential was constant $(159 \pm 11 \mathrm{mV}$, Fig. 2) for approximately 2 months of operation. The relatively high redox potential chosen in $R_{\text {cont }}$ favoured Mn reductive dissolution only, whereas both $\mathrm{As}(\mathrm{V})$ reduction and $\mathrm{Fe}$ reductive dissolution should not be thermodynamically favoured (Fig. 1c). Indeed, $\mathrm{Mn}$ mobilisation was virtually the same in both reactors $\left(R_{\text {cont }}=624 \mu \mathrm{g} \mathrm{g}^{-1}\right.$ vs. $R_{\text {nat }}=632 \mu \mathrm{g} \mathrm{g}^{-1}$ after 52 days, Table 1). Reduced $\mathrm{Fe}^{2+}$ was exclusively found in $R_{\text {nat }}$ (Fig. 4) but not in $R_{\text {cont }}$, where colloidal $\mathrm{Fe}$ was responsible for $\mathrm{Fe}$ mobilisation (Fig. 1b, Table 1). Although not thermodynamically favoured, some As(III) was released in $\mathrm{R}_{\text {cont }}$ (Fig. 3a) in the very beginning of reactor operation (until $\sim 192 \mathrm{~h}$, which corresponds to four exchanges of medium). The fact that As(III) was mobilised only initially at high rate as well as that during most reactor operation, pentavalent arsenic was found in $R_{\text {cont }}$ only (Fig. 3) indicate the source of As(III) being desorption from the solid soil phase as a result of nonequilibrium conditions of liquid-saturated soil samples rather than being a result of As reduction. The amount of As(III) released $\left(\sim 45 \mu \mathrm{g} \mathrm{g}^{-1}=\sim 2 \%\right.$ of total $)$ is in coherence with a

Table 1 Cumulative element mobilisation $[\mu \mathrm{g} / \mathrm{g}]$ after $1248 \mathrm{~h}$ (52 days) of reactor operation

\begin{tabular}{llllllll}
\hline & $\begin{array}{l}\text { As total } \\
\text { dissolved* }\end{array}$ & As(III)* & As(V)* & $\begin{array}{l}\text { Fe total } \\
\text { dissolved }\end{array}$ & $\begin{array}{l}\text { Fe } \\
\text { colloid** }\end{array}$ & $\begin{array}{l}\mathrm{Fe}^{2+} \\
\text { dissolved }\end{array}$ & $\begin{array}{l}\text { Mn total } \\
\text { dissolved }\end{array}$ \\
\hline$R_{\text {nat }}$ & 337 & 189 & 144 & 1448 & 85 & 1364 & 632 \\
$R_{\text {cont }}$ & 181 & 46 & 132 & 578 & 578 & 0 & 625 \\
\hline
\end{tabular}

*As total dissolved by ICP-MS, As(III)/As(V) by LC-ICP-MS

$* * \mathrm{Fe}$ colloid $=\mathrm{Fe}$ total $-\mathrm{Fe}^{2+}$ 

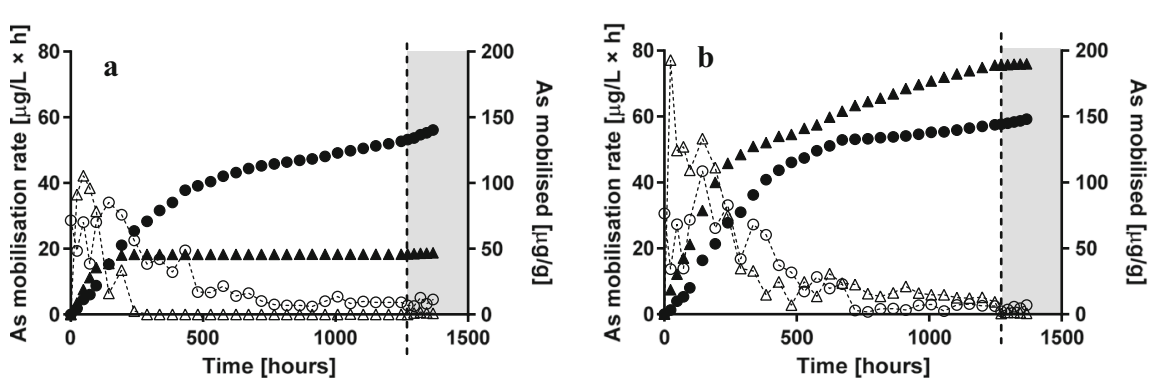

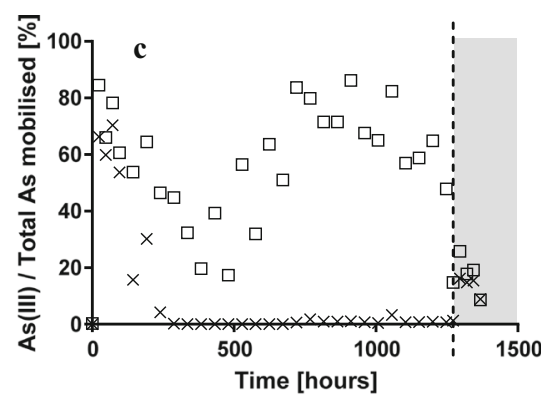

Fig. 3 Arsenic speciation in $R_{\text {cont }}(\mathbf{a})$ and $R_{\text {nat }}(\mathbf{b})$. As(V) (circles; mobilisation rate in open; cumulative mobilised in solid) and As(III) (triangles; mobilisation rate in open; cumulative mobilised in solid).
The dashed line is showing the beginning of oxidising conditions. Share of As(III) on total arsenic mobilised [\%] $\left(R_{\text {nat }}\right.$ in squares, $R_{\text {cont }}$ in crosses) (c) previous XAFS analysis of the initial soil that indicated that although As(III) is present mostly in the oxidised form, a minor fraction $(\sim 3 \%)$ may be present in the reduced form(Rajpert et al. 2016).

The mobilisation rates and the total amount of mobilised Mn were virtually identical in both setups (Fig. 1c), pointing towards Mn reductive dissolution prevailing throughout the reactor operation. Since redox conditions did not favour Fe or As reduction (Fig. 2), As was released either by colloidal Fe (Table 1) or as a result of reductive dissolution of Mn host phases. Both mobilisation mechanisms are of high importance regarding environmental risks. On the one hand, colloidconferred element mobilisation may result in long distance transport of As (and other trace elements (Gomez-Gonzalez et al. 2018)). On the other hand, Mn-sequestered trace elements are easily mobilised because $\mathrm{Mn}$ phases are prone to reductive dissolution at moderate redox conditions (i.e. upon water logging induced by factors such as soil compaction and flooding). The second mechanism is in line with a previous study in which Mn phases, despite their much lower soil concentration, were correlated to mainly conferred As release (Rajpert et al. 2016).

Since Mn reduction occurred in both reactions, the higher overall amount of As released ( $\sim 17$ vs. $\sim 9 \%$ of total) in $R_{\text {nat }}$ was due to either Fe phases (i.e. colloidal mobilisation or reductive dissolution or both) or direct reduction of pentavalent As and desorption of As(III) from the solid phase. The higher share (Fig. 3) and overall amount of As(III) released (Table 1) confirmed the activity of autochthonous bacteria, either As resistant or dissimilatory As(V) reducing (see e.g. Stolz et al. 2006; Drewniak et al. 2010; Uhrynowski et al. 2017; Kruger et al. 2013). The existence and activity of an autochthonous dissimilatory $\mathrm{As}(\mathrm{V})$-reducing bacterial community in the studied soil is in line with correlations observed in a previous study (Rajpert et al. 2016), where its proliferation resulted in a sudden arsenic release after As-bearing Fe and $\mathrm{Mn}$ pools were depleted by reduction.

Because of the considerable amount of As released already at moderately reducing conditions by Mn reductive dissolution, authors recommend implementing detailed monitoring systems and timely (bio)remediation in the Zloty Stok area. A calmative aspect of the study is the fact that in both reactors, induction of oxidising conditions resulted in immediate removal of As from the liquid phase (Fig. 1a) because of the sorption or co-precipitation of the trace element by precipitation of Fe/Mn phases (Fig. 1b, c).

In summary, the redox-stat reactor $R_{\text {cont }}$ allowed suppression of both As and Fe reduction and shed more light on otherwise inconclusive mobilisation mechanisms (i.e. co-existing As(III) desorption, Mn(IV) reduction, As(V) reduction, colloidal Fe mobilisation and reductive Fe dissolution as occurring mechanisms in $R_{\text {nat }}$ ). The technology described here is not limited to the study of As mobilisation and sequestration mechanisms, but can be expanded to study redox transformations of any major and trace elements (e.g. Fe, Mn, C, P, N, S, Cr, Cu, Co, As, Sb, $\mathrm{Se}, \mathrm{Hg}, \mathrm{Tc}, \mathrm{U})$. The detailed understanding of redox processes governing biogeochemical cycles of such (trace) elements is a key for both environmental risk analysis (as speciation determines bioavailability, toxicity and mobility) as well as exploitation of mechanisms in the frame of new (bio)remediation strategies. A few examples below

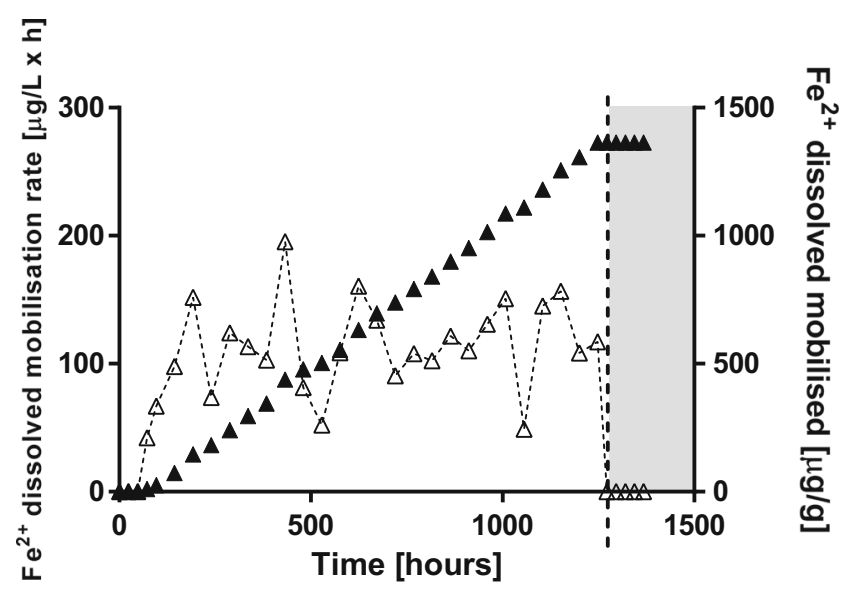

Fig. $4 \mathrm{Fe}^{2+}$ in $R_{\text {nat }}$ in terms of elemental mobilisation rate (open symbols, primary $Y$-axis) and total element mobilised (solid symbols, secondary $Y$ axis). The dashed line is representing the beginning of oxidising conditions. Note, that no $\mathrm{Fe}^{2+}$ was detected in $R_{\text {cont }}$ 
underline the potential use of redox-stat bioreactors. Recently, a considerable seasonal variability of Sb leaching was found in outdoor lysimeters containing contaminated shooting range soils (Hockmann et al. 2015). Although under drained (i.e. high redox) conditions, high amount of $\mathrm{Sb}$ was mobilised (40 to $110 \mathrm{ppb}$ in summer and winter, respectively), reducing conditions led to a fraction of $\mathrm{Sb}$ leaching (2-5 ppb), which was assigned to increased sorption of $\mathrm{Sb}$ (III) to $\mathrm{Fe} / \mathrm{Mn}$ phases. With the proposed redoxstat CSTR, one may treat this soil forcing the redox conditions similar to those in drained lysimeters, preventing $\mathrm{Sb}(\mathrm{V})$ reduction to $\mathrm{Sb}(\mathrm{III})$, thus mobilising and ultimately removing $\mathrm{Sb}$ from contaminated soil.

Stimulating autochthonous dissimilatory metal-reducing microorganisms to remove hexavalent $\mathrm{U}(\mathrm{VI})$ from aquifers by uraninite-U(IV) precipitation has been suggested to prevent further downgradient spread of groundwater contamination (Anderson et al. 2003). However, the long-term reduction of U(VI) to U(IV) can be maintained only by suppression of autochthonous sulphate-reducing bacteria, since sulphide inhibits metal reducers. The application of the redox-stat reactor in actively preventing sulphate-reducing conditions might thus help to improve bioremediation of uraniumcontaminated media.

Microbial bioremediation of selenium (Se) contamination usually exploits the conversion of water soluble, toxic $\mathrm{Se}$ oxyanions [Se(VI), Se(IV)] to water insoluble, elemental Se, which might be easily separated from the aqueous phase (Buchs et al. 2013). However, there is a risk of formation of selenide species at strongly reducing conditions. In metal-rich environments, selenide formation is of less concern (since metal selenides are extremely poorly water soluble) (Lenz et al. 2011). However, when metal as selenide scavengers are depleted, highly toxic $\mathrm{H}_{2} \mathrm{Se}$ may evolve from the aqueous phase. Therefore, a redox stat can be used to set $E_{\mathrm{h}}$ to values sufficiently low for allowing (Se) oxyanion reduction yet high enough to prevent formation of hydrogen selenide.

In summary, this study shed light on the role of the main host phases in arsenic mobilisation via suppression of underlying redox reactions. This and the few further examples provided (i.e. Sb, $\mathrm{U}$ and $\mathrm{Se}$ ) underline the promising application of redox-stat systems in the study of biogeochemical cycles and in bioremediation of redox-sensitive trace elements.

Acknowledgments The support of the HLS scholarship from University of Applied Sciences and Arts Northwestern Switzerland is gratefully acknowledged.

\section{Compliance with ethical standards}

All authors certify that this manuscript contains the original data obtained during research activities and have not been published before. This article does not contain any studies performed with human participants or with animals.
Conflict of interest The authors declare that they have no conflict of interest.

Open Access This article is distributed under the terms of the Creative Commons Attribution 4.0 International License (http:// creativecommons.org/licenses/by/4.0/), which permits unrestricted use, distribution, and reproduction in any medium, provided you give appropriate credit to the original author(s) and the source, provide a link to the Creative Commons license, and indicate if changes were made.

\section{References}

Anderson RT, Vrionis HA, Ortiz-Bernad I, Resch CT, Long PE, Dayvault R, Karp K, Marutzky S, Metzler DR, Peacock A, White DC, Lowe M, Lovley DR (2003) Stimulating the in situ activity of Geobacter species to remove uranium from the groundwater of a uraniumcontaminated aquifer. Appl Environ Microbiol 69:5884-5891. https://doi.org/10.1128/AEM.69.10.5884-5891.2003

Borch T, Kretzschmar R, Kappler A, Van Cappellen P, Ginder-Vogel M, Voegelin A, Campbell K (2010) Biogeochemical redox processes and their impact on contaminant dynamics. Environ Sci Technol 44: 15-23. https://doi.org/10.1021/es9026248

Buchs B, Evangelou MWH, Winkel LHE, Lenz M (2013) Colloidal properties of nanoparticular biogenic selenium govern environmental fate and bioremediation effectiveness. Environ Sci Technol 47: 2401-2407. https://doi.org/10.1021/es304940s

Couture R-M, Charlet L, Markelova E, Madé B, Parsons CT (2015) Onoff mobilization of contaminants in soils during redox oscillations. Environ Sci Technol 49:3015-3023. https://doi.org/10.1021/ es5061879

Drewniak L, Matlakowska R, Rewerski B, Sklodowska A (2010) Arsenic release from gold mine rocks mediated by the activity of indigenous bacteria. Hydrometallurgy 104:437-442. https://doi.org/10.1016/j. hydromet.2010.02.025

Ehlert K, Mikutta C, Kretzschmar R (2014) Impact of birnessite on arsenic and iron speciation during microbial reduction of arsenic-bearing ferrihydrite. Environ Sci Technol 48:11320-11329. https://doi.org/ $10.1021 / \mathrm{es} 5031323$

Fadrus H, Malý J (1975) Suppression of iron(III) interference in the determination of iron(II) in water by the 1,10-phenanthroline method. Analyst 100:549-554. https://doi.org/10.1039/an9750000549

Gallagher PA, Schwegel CA, Parks A, Gamble BM, Wymer L, Creed JT (2004) Preservation of As(III) and As(V) in drinking water supply samples from across the United States using EDTA and acetic acid as a means of minimizing iron-arsenic coprecipitation. Environ Sci Technol 38:2919-2927. https://doi.org/10.1021/es035071n

Giménez J, Martínez M, de Pablo J, Rovira M, Duro L (2007) Arsenic sorption onto natural hematite, magnetite, and goethite. J Hazard Mater 141:575-580. https://doi.org/10.1016/j.jhazmat.2006.07.020

Gomez-Gonzalez MA, Villalobos M, Marco JF, Garcia-Guinea J, Bolea E, Laborda F, Garrido F (2018) Iron oxide - clay composite vectors on long-distance transport of arsenic and toxic metals in miningaffected areas. Chemosphere 197:759-767. https://doi.org/10. 1016/j.chemosphere.2018.01.100

Hockmann K, Lenz M, Tandy S, Nachtegaal M, Janousch M, Schulin R (2014) Release of antimony from contaminated soil induced by redox changes. J Hazard Mater 275:215-221. https://doi.org/10. 1016/j.jhazmat.2014.04.065

Hockmann K, Tandy S, Lenz M, Reiser R, Conesa HM, Keller M, Studer B, Schulin R (2015) Antimony retention and release from drained and waterlogged shooting range soil under field conditions. 
Chemosphere 134:536-543. https://doi.org/10.1016/j.chemosphere. 2014.12.020

Karczewska A, Krysiak A, Mokrzycka D, Jezierski P, Szopka K (2013) Arsenic distribution in soils of a former As mining area and processing. Pol J Environ Stud 22:175-181

Kneebone PE, Hering JG (2000) Behavior of arsenic and other redoxsensitive elements in Crowley Lake, CA: a reservoir in the Los Angeles aqueduct system. Environ Sci Technol 34:4307-4312. https://doi.org/10.1021/es000923u

Kruger MC, Bertin PN, Heipieper HJ, Arsène-Ploetze F (2013) Bacterial metabolism of environmental arsenic - mechanisms and biotechnological applications. Appl Microbiol Biotechnol 97:3827-3841. https://doi.org/10.1007/s00253-013-4838-5

Krysiak A, Karczewska A (2007) Arsenic extractability in soils in the areas of former arsenic mining and smelting, SW Poland. Sci Total Environ 379:190-200. https://doi.org/10.1016/j.scitotenv.2006.09. 031

Lenz M, Van Hullebusch ED, Farges F, Nikitenko S, Corvini PFX, Lens PNL (2011) Combined speciation analysis by X-ray absorption near-edge structure spectroscopy, ion chromatography, and solidphase microextraction gas chromatography-mass spectrometry to evaluate biotreatment of concentrated selenium wastewaters. Environ Sci Technol 45:1067-1073. https://doi.org/10.1021/ es 1022619

Marszałek H, Wąsik M (2000) Influence of arsenic-bearing gold deposits on water quality in Zloty Stok mining area (SW Poland). Environ Geol 39:888-892. https://doi.org/10.1007/s002549900036

Masscheleyn PH, Delaune RD, Patrick WH (1991) Effect of redox potential and $\mathrm{pH}$ on arsenic speciation and solubility in a contaminated soil. Environ Sci Technol 25:1414-1419. https://doi.org/10.1021/ es00020a008

Rajpert L, Kolvenbach BA, Ammann EM, Hockmann K, Nachtegaal M, Eiche E, Schäffer A, Corvini PFX, Skłodowska A, Lenz M (2016) Arsenic mobilization from historically contaminated mining soils in a continuously operated bioreactor: implications for risk assessment. Environ Sci Technol 50:9124-9132. https://doi.org/10.1021/acs.est. 6 b02037

Stolz JF, Basu P, Santini JM, Oremland RS (2006) Arsenic and selenium in microbial metabolism. Annu Rev Microbiol 60:107-130. https:// doi.org/10.1146/annurev.micro.60.080805.142053

Takeno N (2005) Atlas of Eh-pH diagrams. Intercomparison of thermodynamic databases. Geological Survey of Japan Open File Report No 419

Uhrynowski W, Debiec K, Sklodowska A, Drewniak L (2017) The role of dissimilatory arsenate reducing bacteria in the biogeochemical cycle of arsenic based on the physiological and functional analysis of Aeromonas sp. O23A. Sci Total Environ 598:680-689. https:// doi.org/10.1016/j.scitotenv.2017.04.137

Zhang C, Yu Z, Zeng G, Jiang M, Yang Z, Cui F, Zhu M, Shen L, Hu L (2014) Effects of sediment geochemical properties on heavy metal bioavailability. Environ Int 73:270-281. https://doi.org/10.1016/j. envint.2014.08.010

Zimmermann YS, Schäffer A, Corvini PFX, Lenz M (2013) Thin-film photovoltaic cells: long-term metal(loid) leaching at their end-oflife. Environ Sci Technol 47:13151-13159. https://doi.org/10. $1021 / \mathrm{es} 402969 \mathrm{c}$ 